\title{
NJALAPI SEBAGAI STRATEGI PEMBELAJARAN PADA MATAKULIAH KETERAMPILAN BERBICARA PRODI PENDIDIKAN BAHASA INGGRIS UNIVERSITAS PRIMA INDONESIA
}

\author{
Natalia Widya Pasca Tarigan ${ }^{1}$, Yenita Br.Sembiring ${ }^{2}$ \\ Program Studi Pendidikan Bahasa Inggris \\ Universitas Prima Indonesia \\ Corresponding Author: yenitasembiring@unprimdn.ac.id
}

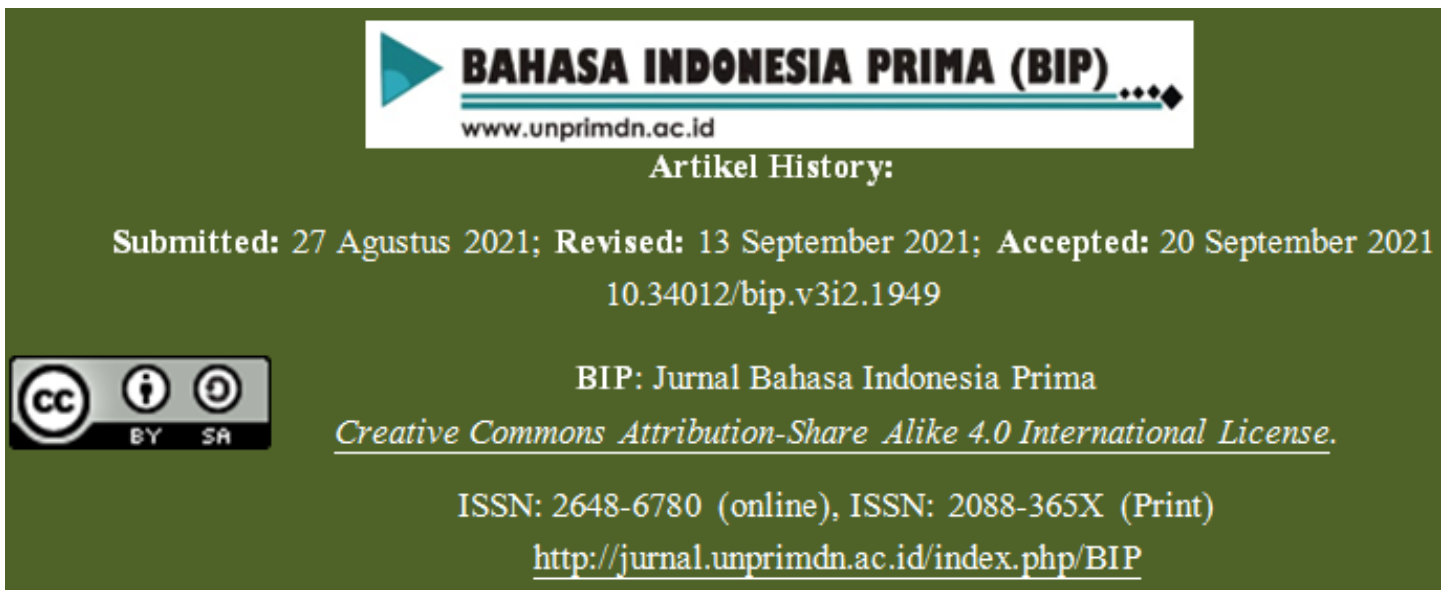

Abstrak-Penelitian ini dilakukan untuk menemukan bentuk dan bagaimana proses komunikasi Njalapi pada suku Karo sebagai strategi pembelajaranketerampilan berbicara pada program studi pendidikan bahasa Inggris Universitas Prima Indonesia.Penelitian ini menggunakan rancangan penelitian diskriptif kualitatif. Penelitian ini melibatkan informan sebagai sumber informasi untuk data penelitian. Wawancara digunakan sebagai alat pengumpulan data. Penelitian dilakukan di tiga wilayah domisili suku karo yaitu kabupaten Deli Serdang, kabupaten Langkat, dan Kabupaten Karo.Teknik yang digunakan oleh peneliti untuk menganalisis data adalah teknik triangulasi data yang sudah dikumpulkan akan dianalisis berdasarkan tiga tahapan, yaitu: tahapan reduksi data, tahapan penyajian data dan tahapan penarikan kesimpulan. Luaran dari penelitian ini adalah strategi pembelajran yang dapat digunakan pada pembelajaran keterampilan berbicara dan publikasi artikel. Artikel ini adalah luaran wajib Penelitian Dosen Pemula 2019 Tahun Anggaran 2020 yang didanai oleh DRPM Ristekdikti.

Kata kunci: njalpi, strategi pembelajaran, keterampilan berbicara

\section{A. Pendahuluan}

Pembelajaran bahasa asing khususnya bahasa Inggris adalah salah satu meteri belajar yang harus diajarakan pada peserta didik di Indonesia. Bahasa Inggris tersebut diajarkan kepada peserta didik mulai dari tingkat dasar sampai ke perguruan tinggi. Namun realitanya di lapangan, hasil akhir dari pembelajaran bahasa Inggris pada umumnya kurang memuasakan. Rata-rata nilai akhir untuk matapelajaran ini masih rendah. Hal ini dapat disebabkan oleh banyak faktor. Diantaranya yaitu, minat belajar peserta didik dan suasana belajar yang kurang mendukung proses pembelajaran. Berdasarkan keterangan dari 
peserta didik yang diperoleh melalui observasi lapangan, banyak dari mereka yang merasa kurang berminat untuk belajar karena menurut mereka cara mengajar pendidik yang monoton menggunakan model atau startegi belajar yang itu- itu saja. Berdasarkan penjelasan ini maka peneliti berkesimpulan bahwa perlu adanya model atau strategi baru untuk mengajarkan bahasa Inggris khussusnya keterampilan berbicara.

Berbicara dapat didefinisikan sebagai proses penyampaian pesan, perasaan, ide, dan pikiran tentang hal tertentu yang membutuhkan keterampilan dalam mengungkakannya secara lisan agar makna pembicaraan dapat tersampikan dengan baik dari pembicara kepada pendengar. Berbicara membutuhkan keterampilan. Dalam berbicara, para mahasiswa harus mengetahui bahasa tersebut dan harus memiliki kemampuan dalam memproses dalam berkomunikasi . (Harmer, 2001). Derakhshan et al (2016) menambahkan bahwa berbicara tidak hanya harus mengetahui bentuk bahasa, ujaran, tetapi juga harus menguasai situasi dimana pembicaraan itu berlangsung). Selain itu ada juga elemen-elemen penting yang harus diperhatikan dalam proses berbicara proses berbicara yaitu :(1) bunyi yang saling berhubungan satu dengan yang lain, hal ini ditandai dengan proses asimilasi, (2) hal-hal yang berhubungan dengan ekspresi misalnya perubahan tekanan suara yang bisa mengisyaratkan emosi si pembicara (3) tata bahasa dan kosakata.

Mujiyanto et al (2000) dalam Dewi (2017) mengatakan bahwa keterampilan berbicara merupakan hal yang sangat penting, karena seseorang yang mahir berbicara akan mudah menguasai seseorang atau massa dan secara tidak langsung akan mampumemaparkan gagasannya sehingga dapat mudah diterima oleh orang lain. Dengan kata lain, bahwa dengan kemahiran berbicara seseorang akan mempunyai manfaat bagi orang lain atau masyarakat misalnya dipercayai menjadi pemimpin. Untuk meningkatkan keterampilan berbicara dalam pembelajaran Bahasa khususnya Bahasa Inggris ada beberapa model dan strategi komunikasiyang dapat digunakan. Namun untuk membatasi pembahasan dalam penelitian ini, maka peneliti hanya akan meneliti penggunaan strategi khususnya strategi komunikasi suku karo Njalapi sebagai strategi pembelajaran pada mata kuliah berbicara

Alasan peneliti untuk menggunakan strategi baru cukup kuat. Hal ini dapat dilihat dari adanya penelitian terdahulu yang dilakukan untuk tujuan serupa. Salah satunya adalah Darmayenti \& Nofiadri (2015) dengan judul Mingle Model for Teaching English Speaking Skills for College Students. Penelitian tersebut mengkaji penggunaan model belajar Mingel terhadap kemampuan berbicara mahasiswa di Universitas Imam Bonjol Padang. Dari hasil olah data ditemukan bahwa penggunaan model Mingel berpengaruh terhadap kemampuan berbicara mahasiswa Bahasa Inggris di tingkat perguruan tinggi khususnya di program studi bahasa Inggris diajarkan melalui 3 jenis keterampilan yaitu keterampilaan menyimak, keterampilan membaca, dan keterampilan berbicara. Dalam penelitian ini, peneliti memfokuskan kajian hanya terhadap keterampilan berbicara dan strategi yang dapat digunakan dalam proses pembelajaran keterampilan berbicara.

Judul penelitian ini yaitu Njalapi Sebagai Strategi Pembelajaran pada Matakuliah Keterampilan Berbicara 
Program Studi Pendidikan Bahasa Inggris Universitas Prima Indonesia. Startegi komunikasi ini diambil dari suku Karo. Prinst (2009:2) mengatakan bahwa suku Karo termasuk ras Proto Melayu (Palaeo Mongoloit) yang bercampur dengan ras Negroid (Negrito). Wilayah tinggal suku Karo terbagi kedalam tiga kabupaten. Yaitu Kabupaten Karo (wilayah yang ditinggali oleh Karo Gugung), kabupaten Deli Serdang (yang ditinggali oleh Karo Jahe) dan kabupaten Langkat (Wilayah yang ditinggali oleh Karo Langkat). Pada umumnya mata pencaharian suku Karo adalah bertani. Masyarakat karo memiliki empat identitas meliputi Merga, Bahasa, kesenian dan Adat Istiadat.

a. Merga adalah identitas masyarakat Karo yang unik. Setiap orang Karo mempunyai merga, yaitu salah satu dari lima merga yang ada pada Suku Karo yaitu Ginting, Sembiring, Perangin-angin, Karo-karo dan Tarigan.

Marga- marga tersebut juga memiliki sub merga:

1. Ginting

Yang termasuk ke dalam mergaa Ginting Adalah: Ginting Munthe, Ginting Manik, Ginting Sinisuka, Ginting Jawak.

2. Sembiring

Yang termasuk kedalam merga Sembiring adalah: Sembiring Kembaren, Sembirng Brahmana, Sembiring Gurukinayan, Sembiring Colia, Sembiring Muham, Sembiring Pandia, Sembiring Depari, Sembiring Bunuaji, Sembiring Milala, Sembiring Pelawi.

3. Tarigan Yang termasuk Tarigan adalah:Tarigan Tua, Tarigan
Silangit, Tarigan Sibero, Tarigan Gersang, Tarigan Tambak, Purba, Tarigan Tambak.

4. Perangin-angin

Yang termasuk kedalam merga perangin-angin adalah: Sukatendel, Bangun, Keliat, Pinem, Pencawan, Singarimbun, Limbeng.

5. Karo-karo

Yang termasuk kedalam merga Karo-karo adalah: Ketaren, Purba karo-karo, Sinuhaji, Sinuraya, Kemit, Sinulingga, Kaban, Surbakti, Kacaribu, Sitepu, Barus.

b. Bahasa Karo merupakan bahasa khusus dan mempunyai aksara khusus pula.

c. Kesenian karo yang tradisional yaitu gendang dan pakaian adat.

d. Adat istiadat tertentu yang merupakan identitas orang orang Karo adalah adanya runggu (musyawaraah untuk mefakat) dan Njalapi dalam acara perkawinan dan acara data lainnya serta Ertutur (adat dalam memperkenalkan diri) dan Rebu (pantang bicara dengan kerabat tertentu).

Menurut Sinuhaji (2013) garis keturunan masyarakat Batak Karo menganut azas patri lineal, dimana garis keturunan menurut keturunan ayah. Sedangkan marga merupakan satu faktor yang penting untuk menentukan hubungan (pertalian) keluarga. Setiap laki-laki dan perempuan harus mempunyai marga dilaki (laki-laki) dan beru (perempuan). Di sisi lain hubungan kekeluargaan (kekerabaratan) di dalam masyarakat Karo boleh diketahui dari bertutur, dari bertutur diketahui "orat tutur" (kedudukan setelah bertutur) apakah kita sebagai : kalimbubu, senina, sembunyak, anak beru, puang kalimbubu, anak beru menteri, senina 
sipemeren, senina siperibahanen yang dalam percakapan sehari-hari sering disebut merga silima, tutur siwaluh, rakut sitelu.

Ada banyak strategi komunikasi yang digunakan dalam berbicara pada suku Karo. Salah satunya adalah Njalapi. Njalapi adalah salah satu komunikasi strategi suku karo di Sumatera Utara. Njalapi adalah tahapan lanjutan dari strategi Runggu Rakut Sitelu yang sudah dibahas oleh peneliti pada penelitian sebelumnya. Njalapi adalah proses diskusi yang melibatakan dua kelompok masyarakat yang berkumpul untuk acara pernikahan. (Tarigan:2008). Dua kelompok tersebut terdiri dari satu kelompok dari pihak wanita dan satu kelompok dari pihak pria, dimana masingmasing terdiri dari Sangkep nggeloh (simupus, sipempoken/sinerehken, senina, anak beru tua, anak beru cekoh baka dan anak beru menteri. Masing-masing punya peran dalam proses diskusi. Njalapi dipimpin oleh kepala lingkungan didaerah dimana hajatan dilaksanakan. Jadi dalam hal ini kepala lingkungan berperan sebagai moderator. Ginting (2017) mengatakan bahwa dalam proses Njalapi hal-hal yang dibicarakan adalah pelaksanaan pesta dan adatnya. Judul penelitian ini yaitu Njalapi Sebagai Strategi Pembelajaran pada Matakuliah Keterampilan Berbicara Program Studi Pendidikan Bahasa Inggris Universitas Prima Indonesia. Penelitian ini bertujuan untuk mengetahui bentuk strategi komunikasi suku Karo yaitu Njalapi. Penelitian ini juga bertujuan untuk memberi solusi terhadap permasalahan dalam penguasaan bahasa Inggris sekaligus melestarikan budaya komunikasi suku Karo Njalapi.

\section{B. Metode Penelitian}

Penelitian ini menggunakan metode diskriptif kualitatif.Ary (2010) mengatakan bahwa deskriftif kualitatif desain adalah jenis penelitian dimana tidak ada perlakuan terhadap subjek penelitian. Desain penelitian ini hanya bersifat menggambarkan apa yg terjadi pada satu fenomena.Metode diterapkan untuk memberikan keterangan akurat mengenai strategi komunikasi Njalapi.

Setiap penelitian pasti memiliki instrumen. Dawson (2002)mendefinisikan instrument penelitian sebagai alat yang digunakan untuk mengumpulkan data dalam sebuah penelitian. Terdapat beberapa jenis-jenis intrumen penelitian. Namun dalam penelitian ini, peneliti akan menggunakan instrumen wawancara untuk mengumpulkan data.

Data yang disampaikan dijabarkan secara sistematis dan terperinci dengan menggunakan teknik narasi. Data penelitian ini adalah data lisan berupa informasi yang diperoleh dari para informan. Informan dalam penelitain ini terbagi kedalam tiga daerah. yaitu Karo Gugung (daerah kabupaten Karo), Karo Jahe (Kabupaten Deli Serdang) dan Karo Langkat (Kabupaten Langkat). Setelah data dikumpulkan oleh peneliti melalui informan maka data tersebut akan dianalisis. Teknik yang digunakan oleh peneliti untuk menganalisis data adalah teknik triangulasi. Miles dan Huberman (2007) mendefinisikan teknik triangulasi sebagai salah satu teknik menganalisis data dimana data yang sudah dikumpulkan akan dianalisis berdasarkan tiga tahapan, yaitu: tahapan reduksi data, tahapan penyajian data dan tahapan penarikan kesimpulan. Luaran utama penelitian ini adalah artikel yang dipublikasi pada jurnal SINTA 5 dengan TKT 3 pada tahun pertama.

\section{Hasil Penelitian}


Data penelitian ini adalah hasil wawancara dengan informan dan observasi lapangan. Data diambil dari tiga wilayah domisili suku karo, yaitu dari kabupaten Tanah Karo,Kabupaten Deli Serdang dan kabupaten Langkat. Data diambil berdasarkan dua pertanyaan penelitian yaitu:

1. Apa yang dimaksud dengan strategi komunikasi Njalapi?

2. Bagaimana bentuk strategi komunikasi Njalapi?

3. Bagaimana proses Njalapi terjadi pada komunikasi suku Karo?

Berdasarkan pertanyaaan diatas, maka ditemukan bahwa:

1. Strategi komunikasi Njalapi adalah strategi komunikasi suku Karo yang berfungsi sebagai penegasan dari musyawarah yang dilakukan sebelumnya. Njalapi dilaksanakan pada acara pesta pernikahan. Pesta pernikahan pada suku Karo dibagi pada 2 tahapan yaitu Ngembah belo selambar (lamaran) dan Mata kerja (hari -H pesta).

2. Njalapai pada pesta pernikahan Suku Karo dipimpin oleh kepala desa dimana pesta dilaksanakan. Yang terlibat dalam proses Njalapi adalah:

a. Calon mempelai (baik calon mempelai pria dan wanita)

b. Simupus (orang tua) dari calon mempelai pria dan wanita

c. Senina (saudara kandung orangtua calon mempelai pria dan wanita)

d. Sipempoken dan sinerehken (wali nikah) calon mempelai pria dan wanita

e. Anak beru calon mempelai pria dan wanita

3. Pada proses Njalapi ada alur percakapan yang dilaksanakan yaitu:
1. Kepala desa sebagai moderator bertanya kepada anak beru pihak mempelai pria dan wanita mengenai identitas masing-masing Sangkep geluh (keluarga yang terlibat dalam diskusi yang terdiri dari simupus, sipempoken/sinerehken, senina, anak beru)

2. Anak beru pihak calon mempelai pria dan wanita mengkonfirmasi pertanyaan kepala desa Sangkep geluh (keluarga yang terlibat dalam diskusi yang terdiri dari simupus, sipempoken/sinerehken, senina, anak beru)

3. Kepala desa bertanya kepada anak beru siapa orang tua dari calon mempelai pria dan wanita dan anak beru mengkonfirmasi kepada orangtua calon mempelai pria dan wanita tentang pertanyaan tersebut.

4. Kepala desa bertanya kepada anak beru siapa yang menjadi wali nikah dari calon mempelai pria dan wanita dan anak beru mengkonfirmasi kepada wali nikah calon mempelai pria dan wanita tentang pertanyaan tersebut.

5. Kepala desa bertanya kepada anak beru siapa yang menjadi senina dari orang tua calon mempelai pria dan wanita dan anak beru mengkonfirmasi kepada senina orangtua calon mempelai pria dan wanita tentang pertanyaan tersebut.

6. Kepala desa bertanya kepada anak beru siapa yang menjadi anak beru dari orang tua calon mempelai pria dan wanita dan anak beru mengkonfirmasi kepada anak beru dari orangtua calon mempelai pria dan wanita tentang pertanyaan tersebut. 
7. Kepala desa bertanya kepada anak beru berapa mahar yang dibayarkan oleh calon mempelai pria kepada calon mempelai wanita.

8. Kepala desa menanyakan anak beru tentang Penindih pudun (kesepakatan yang mengikat dan bernilai hukum). Penindih pudun fungsinya jika salah satu calon mempelai membatalkan pernikahan, maka baik calon mempelai pria atau wanita berhak menuntut secara hukum calon mempelai yang mebatalkan pernikahan.

9. Kepala desa menyampaikan kepada anak beru perihal besaran biaya administrasi perkawinan di desa setempat.

\section{Kesimpulan}

Berdasarkan analisis data, maka dapat disimpulkan bahwa:

1. Njalapi adalah strategi komunikasi suku Karo yang berfungsi sebagai penegasan dari musyawarah yang dilakukan sebelumnya. Proses Njalapi pada adat pekawinan suku Karo diawali pada acara lamaran (Ngembah belo selambar) yang kemudian akan diteruskan pada acara peradatan pesta perkawinan.

2. Njalapi dipimpin oleh seorang moderator yakni kepala desa diwilayah acara pesta pernikahan dilaksanakan.Pihak- pihak yang terlibat dalam proses Njalapi adalah:

a. Calon mempelai (baik calon mempelai pria dan wanita)

b. Simupus (orang tua) dari calon mempelai pria dan wanita

c. Sipempoken dan sinerehken (wali nikah) calon mempelai pria dan wanita

d. Anak beru calon mempelai pria dan wanita
3. Proses komunikasi Njalapi yang dilakukan pada pesta pernikahan suku karo dimulai dari hasil runggu (musyawarah) yang dilakukan sebelumnya. Perlu disebutkan bahwa proses komunikasi yang dilakukan oleh kepala desa ketika Njalapi pada hari $-\mathrm{H}$ pesta sama isi pesannya dan isi dialognya dengan yang dilakukan pada yahap nhembah belo selambar (melamar). Hal-hal yang dikonfirmasi pada proses Njalapi adalah:

1. Nama, usia, agaama, nama keluarga (marga) dan domisili dari:

a. Calon mempelai (baik calon mempelai pria dan wanita)

b. Simupus (orang tua) dari calon mempelai pria dan wanita

c. Senina (saudara kandung orangtua calon mempelai pria dan wanita)

d. Sipempoken dan sinerehken (wali nikah) calon mempelai pria dan wanita

2. Mahar pernikahan

3. Penindih pudun

4. Biaya administrasi pernikahan

Dari temuan dan kesimpulan temuan penelitian diatas dapat diketahui bahwa, suku karo memiliki keunikan tersendiri khususnya pada bidang strategi komunikasi. Strategi komunikasi tersebut memiliki fungsi tersendiri dan proses penerapannya memiliki tahapan yang khusus. Alur percakapan dan bentuk strategi tersebut dapat diaplikasikan menjadi salah satu strategi komunikasi khususnya dalam pembelajaran keterampilan berbicara.

Alur diskusi diatas dapat kita lihat dalam gambar berikut ini: 
BIP: Jurnal Bahasa Indonesia Prima Vol. 3, No. 2, 2021, September 2021, PP.

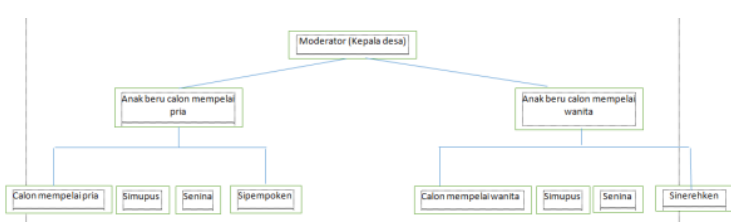

Penerapan alur strategi komunikasi diatas tentunya akan menciptakan atmosfer tersendiri dalam proses pembelajaran dikarenakan adanya penerapan strategi yang baru. Sehingga diharapkan dengan penerapan strategi pembelajaran yang baru dapat memberikan kontribusi signifikan terhadap kemampuan berbicara mahasiswa program studi pendidikan bahasa Inggris Universitas Prima Indonesia.

\section{Daftar Pustaka}

Ary et al. 2010. Introduction to Research in Education. Wadworth. Belmonth. USA.

Darmayenti \& Nofiadri. 2015. Mingle Model For Teaching English Speaking Skill For college Students. Vol. 22, No.1, Februari 2015.Hal 1-9.

Dawson, Catherine. 2002. Practical Research Method. How to Books, ltd.

Derakhshan et al. 2016. Developing EFL Learners' Speaking Ability, Accuracy and Fluency. English language and Literature Studies Vol. 6 No. 2. Hal: 178.

Dewi, Candra. 2017. Peningkatan Keterampilan Berbicara dalam bermain Drama Melalui Model
Pembelajaran Kooperatif Tipe Inside Outside Circle. Jurnal Inovasi Pembelajaran. Vol. 3. No. 2.

Ginting, Seri Ulina Beru. 2017. Semiotik Makna pada Upacara Nembah Belo Selambar Adat Karo Langkat (kajian Semiotika Sosial). Jurnal Pena Indonesia Vo.3 No.2.

Harmer, Jeremy. 2001. How to Teach English. Longman Pearson: Cambridge. London.

Miles, Mathew B dan A, Michael Huberman. 2007. Analisis data kualitatif. Buku Sumber Tentang Metode-metode Baru. Jakarta. UI Press.

Prinst, Darwin. 2002. Kamus KaroIndonesia. Bina media: Medan.

Sinuhaji, Minah. 2013. Pelestarian Adat dalam Upacara Perkawinan Masyarakat Batak Karo Sebagai Atraksi Wisata dalam Menunjang Kepariwisataan di Kabupaten Daerah Tingkat II Karo. Jurnal Geografi. Vo. 5. No. 1.

Tarigan, Sarjani Drs. 2008. Dinamika Orang Karo, Budaya dan Modernisme. Medan Lamerose Press. 